\title{
Modeli atoma u 20. i 21. stoljeću
}

\section{Grba*}

Prva sušačka hrvatska gimnazija u Rijeci, Gajeva 1, 51000 Rijeka

\author{
Sažetak \\ atoma u proteklih stotinjak godina kao i nekih još neodgovorenih pitanja. \\ Ključne riječi \\ Model atoma, Bohrov model atoma, kvantnoteorijski model atoma, \\ kvantnoelektrodinamički model atoma, kvantnokromodinamički model atoma
}

O modelu atoma razmišljalo se još od antičke Grčke pa sve do polovine 20. stoljeća te bi se lako moglo pomisliti da se o atomima zna sve što se uopće može znati. Mnoge činjenice usvoje se već u srednjoj školi, a studenti kemije ili fizike zapravo malo mare kako se to točno gibaju elektroni u atomu ili odakle atomima masa. Doista, kako to da atomi uopće postoje, koji su preduvjeti postojanja atoma onakvih kakvi jesu? U članku je dan pregled osnovnih spoznaja o atomu danas, povijest modela

\section{Uvod: pretkvantnoteorijski atom}

Kako se o atomima već desetljećima poučava u našim školama $^{1,2}$ te su osnovni pojmovi i eksperimentalni rezultati manje-više dobro poznati, a onda i osnovne pojedinosti o različitim modelima atoma kroz povijest filozofije, fizike ili kemije, ovdje je cilj učenicima i studentima izložiti na zanimljiv način neke manje poznate činjenice i dotaknuti se još nerazjašnjenih pitanja o atomskoj strukturi ili temeljnim konstituentima atoma, odnosno osnovnim veličinama kojima su opisani atomi.

lako je atomizam ${ }^{3,4}$ (ili nauk o atomima kao osnovnim građevnim jedinicama svemira) naučavan još od vremena Leukipa i Demokrita a bio je barem spominjan, ako ne i popularan, kroz cijelo razdoblje antike (rimski filozof i pjesnik Lukrecije piše cijeli filozofski spjev posvećen tumačenju svega u svijetu u svjetlu atomizma), sve do prije tristotinjak godina bio je praktički zaboravljen. Atomi se, prema antičkim filozofima, gibaju u praznini (što je za njih predstavljalo upravo ništavilo, a ne tek vakuum nastao nakon što se ukloni zrak). Srednjovjekovna je skolastika smatrala atomistički nauk (izvorno postavljen kao materijalistički) bezbožnim, a obnovljen je tek u djelu Newtona, koji se atomističkom (ili općenito korpuskularnom) hipotezom ponekad koristio. U međuvremenu je, u 17. stoljeću, dokazano postojanje vakuuma, što je dugo bio tabu (poznat je pojam horror vacuui $=$ strah od praznine), slavnim pokusima Torricellija koji su urodili konstrukcijom živinog barometra, ili Guerrickea sa šupljim metalnim polukuglama,

\footnotetext{
*Mr. sc. Marko Grba

e-pošta: marko.grba@skole.hr
}

koje, nakon što je iz njih isisao zrak, nije moglo rastaviti niti nekoliko upregnutih konja. Atomizam je potpuno rehabilitiran u djelu našeg Ruđera Boškovića, isusovačkog učenjaka, koji je, povodeći se uzorom Newtonove mehanike materijalnih točaka među kojima vlada privlačna gravitacijska sila, tumačio uopće sve pojave kao privlačenje ili odbijanje među atomima te za svoj rad primio brojna priznanja i pohvale uglednih znanstvenika i filozofa (poput Faradaya, Maxwella ili J. J. Thomsona). Bošković5,6 je svu materiju vidio kao hijerarhijski organiziranu, počevši od njegovih besprotežnih materijalnih točaka (puncta) koje grade atome, koji grade molekule (hipotezu molekula uvodi 50 godina prije Avogadra!), koje opet izgrađuju makromolekule, i tako sve do makroskopskih tijela. Njegov univerzalni zakon sila imao je vrijediti u nepromijenjenom obliku na svim razinama organizacije materije a dobro poznata krivulja (tj. njezin dio) odlično oponaša Lennard-Jonesove potencijale međumolekulskih međudjelovanja.

Upravo je Boškovićevo djelo, posebice oblik njegove krivulje sila, poslužilo najprije J. J. Thomsonu, otkrivaču elektrona (1897.), za postavljanje tzv. planetarnog modela atoma, koji je on prvi razmatrao kao mogućnost, koji je potom lord Ernest Rutherford preuzeo kao model koji najbolje odgovara njegovim eksperimentima 1911. kada je otkrio atomsku jezgru. Preko Boškovićeve krivulje sila (izvrnute naopako, tako da je odbojni dio ispod apscise) Thomson je nacrtao potencijalne elektronske orbite oko pozitivnog naboja (kao na slici 1.). Pune linije prikazuju dopuštene orbite (kako ih je već Thomson nazvao, dakle prije Bohra!), dok iscrtkane linije prikazuju zabranjene orbite. Dopuštene orbite odgovaraju (prema Thomsonu) Boškovićevim graničnim područjima kohezije, gdje njegove materijalne točke mogu teže boraviti, dok zabranjene 
orbite predstavljaju područja koja Boškovićeve točke izbjegavaju. Naposljetku je Bohr, koji je bio učenik i Thomsona i Rutherforda, preuzeo ideje svojih mentora u paketu, posudivši također formulu za valne duljine linijskog spektra atoma od, sada već dugo zaboravljenog, Waltera Ritza, čemu je pridodao pravila za tzv. kvantne skokove, a sve zajedno postalo je poznato kao Bohrov model atoma. Istina, prije Rutherforda i Bohra trebao je i dokaz da atomi stvarno postoje jer i dalje nisu svi u to bili uvjereni (dapače, neki od najvećih znanstvenika onog vremena bili su zadrti protivnici atomizma, poput kemičara Ostwalda ili fizičara Hertza!). Ključni dokaz u prilog postojanju atoma pružili su radovi Alberta Einsteina iz 1905. u kojima on daje egzaktne proračune atomskih i molekulskih dimenzija za modele prikladne onodobnoj eksperimentalnoj tehnici. Francuz Jean Perrin te je pokuse i proveo i više nije bilo dvojbi niti oko postojanja atoma, niti vakuuma u kojemu se kreću!

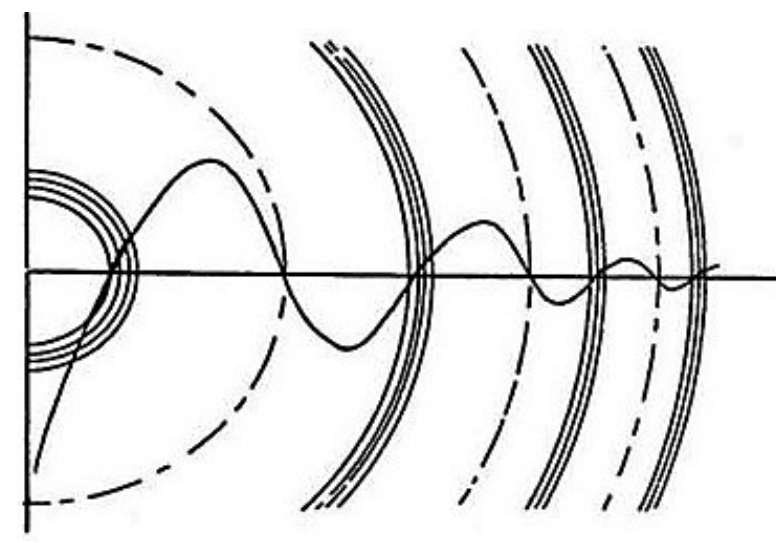

Slika 1 - Boškovićeva krivulja sila superponirana na zamišljene orbite elektrona u atomu prema J. J. Thomsonu

Fig. 1 - Boscovich curve of universal force superimposed on the imagined electron orbits as envisaged by J. J. Thomson

Namjeravajući provjeriti koji je od modela njegova mentora J. J. Thomsona ispravan (onaj tzv. kolača od trešanja*, gdje su negativni elektroni raspoređeni kao trešnje ravnomjerno u pozitivno nabijenom biskvitu, ili onaj minijaturnog Sunčevog sustava), Rutherford ${ }^{7}$ je izveo jedan od najslavnijih pokusa fizike svih vremena a i znanosti uopće, tzv. Rutherfordovo raspršenje na listiću metala. Rutherford je pretpostavio (na osnovi vlastitih proračuna kao i eksperimentalnih i teorijskih istraživanja provedenih do onog vremena) da su zapravo takvi sudari rijetki, suprotno Thomsonovu vjerovanju da bi sudari projektila ( $\alpha$-čestica) s pojedinačnim negativnim nabojima unutar atoma nekog materijala (metala) bili prilično učestali i stoga značajno doprinosili defleksiji čestica-projektila, a to bi onda odgovaralo modelu trešnjina kolača. Prema tome se zakrivljenja putanje projektila uslijed odbijanja pozitivnog naboja neće kompenzirati zakrivljenjima putanje istog projektila uslijed privlačenja sa suprotnim nabojima, kako bi zahtijevao model trešnjina kolača, već će tu-i-tamo, iako relativno rijetko, doći do

*Na engleskom plum pudding model, što bi odgovaralo kolaču od šljiva, no kako mi češće pravimo sličan kolač od trešanja, bolje je možda govoriti model kolača od trešanja. primjetne defleksije, a u iznimno rijetkim slučajevima (tim češće što je atom teži, a to znači i većeg pozitivnog naboja) i pod vrlo velikim kutem od prvotnog pravca gibanja. Usporedbeno su dva modela prikazana na slici 2 .
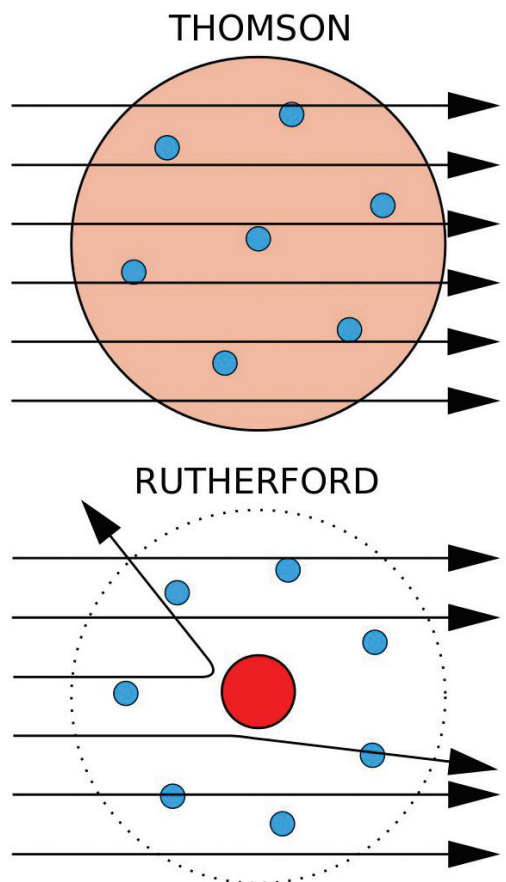

Slika 2 - Defleksije putanja $\alpha$-čestica u Thomsonovu modelu trešnjina kolača i Thomson-Rutherfordovu modelu planetnog sustava

Fig. 2 - Deflections of paths of $\alpha$-particles as in Thomson plum pudding model and Thomson-Rutherford planetary model

Rutherford je dobio rezultate kakvi bi slijedili prema planetarnom modelu, u kojem je pozitivni naboj u sredini atoma, dok elektroni kruže oko atomske jezgre. Iz svojih rezultata Rutherford je izvukao ne jedan, već tri kapitalna zaključka. Prvo: atom ima pozitivnu i u odnosu na veličinu atoma vrlo malu jezgru (na što ukazuje iznimno mala učestalost sudara pod velikim kutevima otklona koji su posljedica praktički čeonog sudara s jezgrom atoma); drugo: atom je većinom prazan prostor - zapravo 99,9999999999996 \% prazan** u slučaju atoma vodika (jer velika većina projektila jednostavno prođe kroz atome); treće: oko pozitivno nabijene jezgre gibaju se negativno nabijeni elektroni koji su još mnogo puta manji (do danas se ne zna točno koliko puta manji!). Dapače Rutherford je odmah zaključio i da ako se pretpostavi da vodikov atom ima samo jedan pozitivan naboj, tada $\alpha$-čestica, imajući dva, mora biti jezgra helija. Također je dalje naslutio, su-

\footnotetext{
** Učenicima se može dati na jednom od uvodnih satova srednjoškolske, ali i osnovnoškolske, kemije sprovesti elementarni račun postotka neispunjenog prostora u atomu, tako da podijele volumen protona (jezgre vodika) s volumenom atoma. Volumeni se mogu uzeti kao volumeni kugle, a učenicima samo treba reći polumjer atoma $\left(\approx 10^{-10} \mathrm{~m}\right)$ i polumjer protona $\left(\approx 10^{-15} \mathrm{~m}\right)$
} 
kladno staroj Proutovoj hipotezi da su svi teži atomi sastavljeni od vodika, da su jezgre svih težih atoma izgrađene od jezgre atoma vodika, koju je prikladno nazvao protonom (od grč. protos $=$ prvi).

Najbolje bi bilo učenicima objasniti povijest modeliranja atoma do Rutherforda a onda ih navesti da, uz minimalne upute od profesora, sami izvuku Rutherfordove zaključke. U slučaju naprednijih razreda moglo bi se učenike navesti i da sami zamisle postav Rutherfordova eksperimenta, koji je doista i metodički izvrstan primjer mogućnosti koje se nàdaju u nastavi otkrivanjem uporabom misaonih pokusa (kad već nije moguće takav pokus stvarno izvesti).

PRVI VELIKI ZAKLJUČAK ATOMISTIČKOG MODELA

MATERIJE: Svemir je ne samo većinom prazan prostor $u$

kojem se gibaju atomi, već su i atomi pretežno prazni!

\section{Bohrov model atoma: proto-kvantnoteorijski model}

Na prijelazu iz 19. u 20. st. postalo je jasno da ono što se otad naziva klasičnom fizikom ne može pružiti tumačenje nekoliko novootkrivenih fenomena, a svaki od njih dao je naslutiti da se iza njega krije cijelo neistraženo područje znanja o materijalnom svijetu. Posebno, četiri problema naviještala su krizu u fizici kakve nije bilo još od vremena pronalaska Newtonove mehanike (zapravo utemeljenja matematički zasnovane fizike): otkriće linijskih spektara zračenja atoma (i kasnije molekula); problem nalaženja zakona zračenja crnog tijela; problem tumačenja specifičnih toplinskih kapaciteta kristala; problem tumačenja tzv. fotoelektričnog učinka. Sva četiri problema riješena su (zapravo samo djelomično!) u okviru nerelativističke kvantne teorije. Prvi problem riješio je Niels Bohr (1913.) svojim modelom atoma s kvantnim skokovima; drugi problem riješio je Max Planck i to je prvi egzaktno formuliran zakon kvantne fizike; treći i četvrti problem riješio je Albert Einstein uvođenjem pojma fotona i nove statistike pri brojenju kvantnih čestica (tzv. Bose-Einsteinove statistike).

Bohr ${ }^{8,9}$ je odabrao protumačiti spektre zračenja atoma (i molekula). Dvije su vrste atomskih spektara: emisijski spektar, koji nastaje emisijom elektromagnetskog zračenja iz pobuđenih atoma i sastoji se od niza raznobojnih linija (zapravo pruga raznih širina, što će poslije biti objašnjeno) između kojih su tamna područja, kao da dio spektra nedostaje; apsorpcijski spektar koji nastaje kada atom apsorbira zračenje a izgleda kao negativ emisijskog spektra, tako da umjesto svijetlih pruga emisijskog spektra ima tamna područja i obrnuto. Takvi se spektri nazivaju diskretni ili linijski (što je zapravo varljiv naziv jer su linije zapravo pruge!). Ključni je uvid fizičara prije Bohra bio da u tim spektrima nedostaju valne duljine odnosno frekvencije, što će reći da nisu kontinuirani kao onaj duginih boja koji nastaje od npr. bijele svjetlosti Sunca propuštene kroz prizmu. Bohru je preostalo pronaći moguće razloge, ili čak mehanizam, proizvodnje takvih diskretnih spektara kao posljedice procesa $u$ atomu.
Već je J. J. Balmer za pojedine spektre, a potom i Walter Ritz*, općenito, pronašao formulu kojom su spektralne linije dane kao razlike recipročnih vrijednosti kvadrata malih prirodnih brojeva, što je ponukalo Bohra da ih u atomu vidi kao nekakve stepenice ili, znanstvenije, energijske razine. Dobro poznata formula za atom vodika glasi:

$$
\frac{1}{\lambda}=R_{0}\left(\frac{1}{n^{2}}-\frac{1}{m^{2}}\right)
$$

gdje je $\lambda$ valna duljina zračenja, $n$ i $m$ prirodni brojevi ( $u$ Bohrovu modelu uzastopni redni brojevi energijskih razina) a $R_{0}=1,097 \cdot 10^{7} \mathrm{~m}^{-1} \mathrm{tzv}$. Rydbergova konstanta (prema J. R. Rydbergu, koji je među prvima pokazao da općenitija formula zadovoljava eksperimentalne podatke). ${ }^{10}$

Bohr je prihvatio Thomson-Rutherfordov planetarni model i Boškovićeve dopuštene i zabranjene staze kojima se u Bohrovu modelu kreću elektroni kružeći oko jezgre atoma na točno određenim udaljenostima koje pak odgovaraju točno određenim energijama, odnosno energijskim razinama (nivoima) koje Bohr naziva stacionarnim stanjima. Osnovna je ideja da elektron nikada ne može boraviti između dvaju dopuštenih nivoa a da atom emitira ili apsorbira energiju samo kada elektron prelazi s jednog nivoa na drugi; proces emisije događa se pri prijelazu s višeg u niži nivo, a proces apsorpcije, obrnuto, pri prijelazu s nižeg na viši. Izmijenjena energija uvijek je cjelobrojni višekratnik Planckovog kvanta energije i odgovara frekvenciji, odnosno valnoj duljini spektralne linije:

$$
E=h f=E_{n}-E_{m},
$$

gdje je $E$ energija, $f$ frekvencija a $h=6,626 \cdot 10^{-34} \mathrm{~J} \mathrm{~s}$ Planckova konstanta. Oba prijelaza su skokovite izmjene energije no unatoč trudu i vjeri u postojanje kontinuiranog mehanizma prijelaza između nivoa, Bohr ga nikada nije uspio pronaći. Nije to pošlo za rukom niti kojem drugom fizičaru ili kemičaru otada, te se danas prihvaća da za skokove nema mehanizma, odnosno da su oni indeterministički, tj. nasumični i nepredvidljivi. To znači da se ne zna i ne može znati (!) kada će do skoka doći i na koji način do njega dolazi. Dakle, Bohrov model ne objašnjava kvantne skokove a ne daje odgovore niti na neka druga vrlo zanimljiva pitanja za koja nije još isključeno da uopće nemaju odgovora. Naime, kako se to točno gibaju elektroni u atomu? Iz Maxwellove elektrodinamike je poznato da naboji u ubrzanom gibanju (u slučaju elektrona u atomu to bi bilo kruženje, što podrazumijeva centripetalnu akceleraciju) zrače svoju kinetičku energiju i ubrzo kolabiraju na jezgru. Što će reći da prema Bohrovu modelu atomi uopće ne bi smjeli postojati! Također, prema Bohrovu modelu, jednom kad se elektron nađe $\mathrm{u}$ nekom stacionarnom stanju, on tamo potencijalno može provesti cijelu vječnost, jer nema pravila niti mehanizma koji određuje kada i kako se zbiva prijelaz u drugi nivo. Na neka od tih pitanja daju odgovor kasnije razvijeni modeli o kojima slijedi rasprava.

\footnotetext{
*Walter Ritz bio je svojevremeno jedan od najuglednijih fizičara u svijetu, Einsteinov kolega sa studija i jedan od takmaca u rješavanju problema relativnosti gibanja i prirode svjetlosnog medija etera. Nažalost, umire vrlo mlad od tuberkuloze i dan-danas je jedva spominjan.
} 


\section{Kvantnoteorijski model}

Osim gore navedenih, bilo je još problema s Bohrovim modelom: najozbiljniji prigovor upućen je načinu na koji je Bohr izveo svoj model. Naime, Bohr je primjenjujući pretpostavke Newtonove mehanike materijalne točke, pridodavši Planckovu hipotezu kvantiziranog elektromagnetskog zračenja, napravio himeru, tj. model za koji se ubrzo shvatilo da ne opisuje i ne može opisivati prave atome. Ponajprije, zašto postoje stacionarna stanja, zabranjene i dopuštene elektronske orbite kad tako nešto ne predviđa Newtonova mehanika? Nadalje, kako protumačiti kvantne skokove i k tomu još njihovu načelno nasumičnu pojavu, ta nije li Newtonova mehanika strogo deterministička i kauzalna? Napokon, model je opisivao isključivo spektre vodika i srodnih monovalentnih sustava. Očita je bila potreba za suvislijim i atomskoj zbilji bližim modelom. Prvi takav model napravio je Erwin Schrödinger i to je bio ujedno i prvi kvantnoteorijski model. ${ }^{12,14}$

Općenito i krajnje pojednostavljeno govoreći, kvantna teorija nastaje 1920-ih kao nastojanje da se pruži potpun i konzistentan opis atomskih i molekulskih sustava, ponajprije diskretnih spektara zračenja, njihovih magnetskih i termičkih svojstava, a onda i same strukture atoma i molekula. Valja odmah upozoriti na to da je zapravo najmanje rasvijetljen problem strukture atoma jer, i unatoč proračunavanju energija kvantnih skokova ili vjerojatnosti nalaženja elektrona oko jezgre nekog atoma, kvantna teorija sa sigurnošću (100 \% vjerojatnosti) ne daje prostorno-vremenski opis gibanja subatomskih čestica niti njihova svojstva (položaj, energiju, impuls, itd.). Postavlja se pitanje zašto je tomu tako i kakvim točno sredstvima kvantna teorija opisuje atome i druge kvantne objekte?

Koordinate položaja čestice i njezino vrijeme nalaženja i dalje ulaze kao nezavisne varijable u osnovnu jednadžbu kvantne mehanike, ali uz dvije ograde: prvo, to nije jedini način na koji je moguće izabrati nezavisne varijable jer postoje i druge tzv. reprezentacije pored koordinatne, pa zapravo ništa ne govori da su prostor i vrijeme ujedno i temeljne veličine opisa kvantne zbilje; drugo, nezavisne varijable zapravo ulaze u jednadžbu neizravno, preko tzv. valne funkcije u Schrödingerovoj formulaciji teorije. ${ }^{*}$ Kako osnovna ili Schrödingerova jednadžba zapravo ne daje za rezultat putanje čestica u prostoru i vremenu, tako da i nije pravilno govoriti o kvantnoj mehanici, jer se tu ne radi ni o kakvom mehaničkom opisu, već je bolje kazati kvantna teorija. Valne funkcije kao rješenja Schrödingerove jednadžbe u slučaju atoma ili molekula nazivaju se i orbitale, o kojima je, kao i o formalizmu kvantne teorije, autor više pisao u rujanskom broju ovog časopisa, te o tim temama ovdje neće biti mnogo govora. ${ }^{12}$ Predmet rasprave u nastavku bit će ponajprije struktura atoma i problem tumačenja kvantnih stanja i kvantnih skokova između tih stanja, što je i fokus u srednjoškolskom kurikulu.

Kako definirati kvantno stanje, recimo elektrona u vodikovu atomu, i dalje je predmet rasprave i istraživanja. Naime,

\footnotetext{
* Dan-danas postoji devet formulacija kvantne teorije, pod čime se misli devet bitno različitih matematičkih struktura teorije, dočim postoji preko deset manje ili više srodnih interpretacija, tj. gledišta o tomu kako protumačiti iskaze kvantne teorije.
}

kako postoji više reprezentacija istog sustava, a to znači i istih stanja, to nije moguće jednostavno reći, stanje znači energijsko stanje ili položaj neke od Bohrovih orbita. Činjenica jest da i pri statističkom opisu elektrona u atomu na kraju proizlazi da su najvjerojatniji položaji uzduž Bohrovih semi-klasičnih orbita, a najmanje izgledni položaji uzduž zabranjenih područja, međutim - a što valja posebno naglasiti učenicima i studentima - tu treba biti iznimno oprezan u formulaciji. Postoje manje ili više vjerojatni položaji uzduž Bohrovih orbita, no ne postoje i orbite same, barem ne kao kontinuirane krivulje. Jer ako bi postojale putanje po kojima bi oko jezgre obilazili elektroni, tada bi se, prema već spomenutom teoremu Maxwellove elektrodinamike, elektroni prije ili kasnije obrušili na jezgru, atoma bi trenutno nestalo a sva materija bi se skupila praktički na volumen ništice, i svijet bi očito izgledao bitno drugačije no što izgleda!

Ako sad čitatelj(ica) pomišlja da je to bizarno, tada neka se dobro spremi na nastavak priče o kvantnim stanjima. Schrödinger je svoju jednadžbu, temeljnu jednadžbu kvantne teorije, postavio za pretpostavljene valove materije Louisa de Brogliea, koji je otprilike u isto vrijeme razmatrao analogiju između dvojne prirode svjetlosti (elektromagnetni val-foton) koja je upravo tada bila dokazana s mogućom dvojnom prirodom ostatka materije, tj. da se i čestice s masom mogu pod određenim uvjetima ponašati poput valova materije. Schrödinger je u stvari pogodio da je ponašanje elektrona u atomu jedan takav primjer! Schrödingerova jednadžba, koja doista egzaktno rješava problem atomskih spektara vodikova i sličnih atoma a načelno je točna i za atome ostalih elemenata (makar ju je za njih moguće riješiti samo aproksimativno!), do dana današnjeg nije izvedena iz prvih pretpostavki, a da bi se svi fizičari i kemičari oko njih složili. Ubrzo nakon što je Schrödinger postavio svoju jednadžbu, također se ustanovilo da elektronski valovi ne mogu postojati. Oni bi ponajprije morali biti dobro lokalizirani oko stacionarnih stanja, što bi odgovaralo tzv. valnim paketima (kao na slici 3), koji bi se, praktički čim bi nastali, raširili i na taj način opet delokalizirali elektrone (brzina širenja takvog valnog paketa bila bi nekoliko milijardi kilometara u sekundi): elektroni bi se svi razletjeli iz atoma! Ali tada nužno ostajemo pri kvantnim skokovima i, posljedično indeterminističkom shvaćanju osnovnih procesa u prirodi. To se Schrödingeru nikako nije sviđalo, te je on do kraja svojeg dugog života ostao pristalica valnog modela materije, unatoč nikada razriješenim problemima koji su ga pratili. ${ }^{16,17}$

Međutim, kako rekosmo, elektroni na neki način ipak slijede model vala kada su sputani privlačnim potencijalom atomske jezgre. ${ }^{12}$ Obasjamo li atom svjetlošću određene frekvencije, nakon kratkog vremena (obično reda veličine nanosekunde) elektron preskoči iz nižeg u viši energijski nivo. Kako vrijedi zakon očuvanja energije a elektron apsorbira cijeli i nedjeljivi kvant energije, vrijeme apsorpcije fotona mora biti otprilike jednako trajanju kvantnog skoka. Da je elektron valni paket, tada bi transfer energije tekao postupno, tako da bi dio energije s dijelom vala zaostajao na nižem stanju (i međustanjima), dok bi tek dio energije bio prenesen na viši nivo. Ali elektron je opisan valnom jednadžbom a dinamika elektronove pojave na narednom energijskom nivou vjerojatnošću koja se dobije kao kva- 


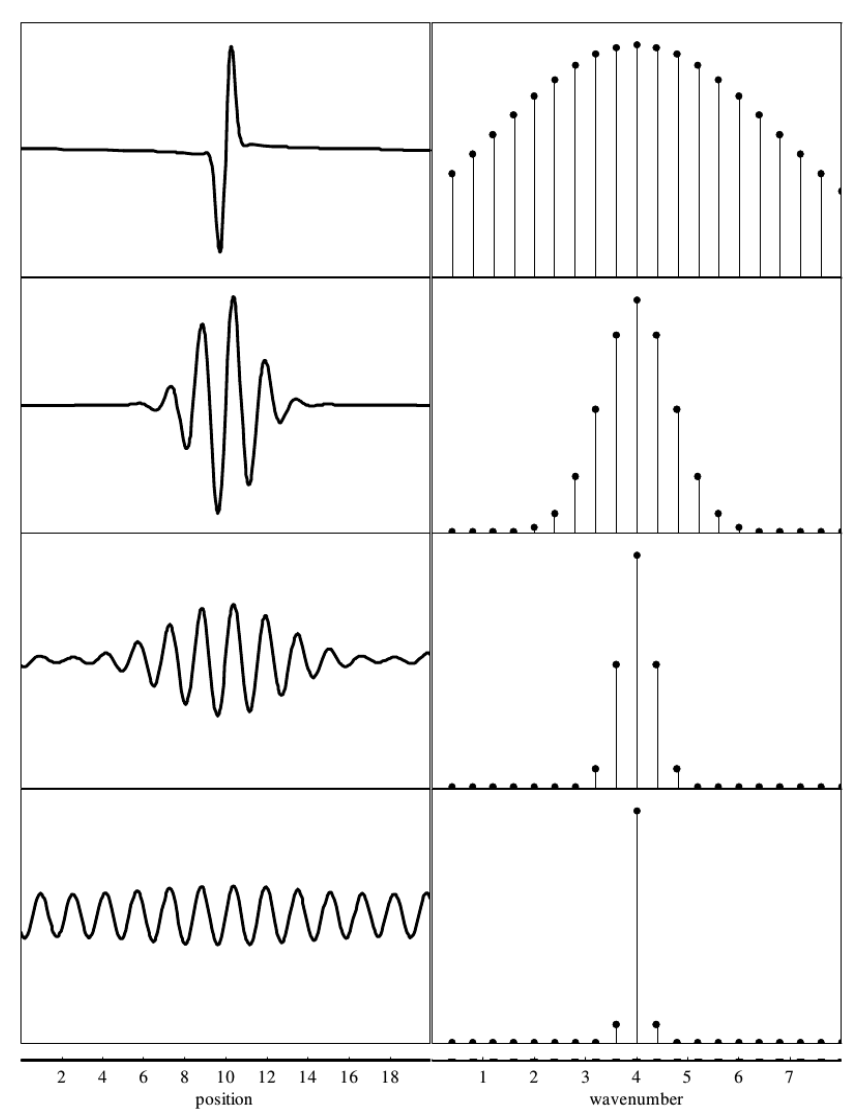

Slika 3 - Valni paket kao rezultat zbroja (superpozicije) nekoliko valova bliskih vrijednosti frekvencija. Kako se valni paket položaja čestice (na lijevo) širi a čestica postaje sve delokaliziranija, tako se valni paket impulsa (na desno) skuplja, čime postaje sve određeniji.

Fig. 3 - A wave packet as a result of a superposition of several waves of closely valued frequencies. As the position wave packet (left hand images) spreads out, and the particle becomes ever more delocalized, the momentum wave packet (right hand images) shrinks, becoming ever more determinate in value.

drat (odnosno modul) kompleksne valne funkcije. Dok se elektron skokovito premješta iz jednog stacionarnog stanja u drugo (što potvrđuju diskretne vrijednosti frekvencija spektralnih linija), vjerojatnost njegova nalaženja u narednom stanju postupno ili kontinuirano raste (što zahtijeva osnovna jednadžba kvantne fizike iz koje se proračunavaju spektralne linije)! Dakle, postoji paradoks: dok se stvarni, materijalni elektron premješta unutar atoma skokovito, poput lokalizirane čestice, vjerojatnost nalaženja elektrona na nekom položaju mijenja se kontinuirano, poput vala, tzv. vala vjerojatnosti. Taj val, dakako, nije materijalan, pa čak nije niti u trodimenzijskom prostoru, već u multidimenzijskom konfiguracijskom prostoru, čiji broj dimenzija ovisi o broju elektrona u atomu. Problem interpretacije tzv. valno-čestične dualnosti i dalje je predmet rasprave, ovisno o kojem se interpretacijskom gledištu radi.

Ako i prihvatimo valove vjerojatnosti kao nužni dio opisa kvantne zbilje, a onda i objašnjenja kvantnih skokova, ostaju još neka pitanja. ${ }^{13}$ Nešto prije Schrödingera Wer- ner Heisenberg postavio je matrični formalizam kvantne teorije čija je matematička osnova bio račun operatora i matrica linearne algebre. Heisenberg je na temelju zamišljenih pokusa, ali i temeljitog proučavanja atomskih spektara, postavio tzv. Heisenbergove relacije neodređenosti. U svijetu atoma i subatomskih čestica nije moguće istovremeno i s proizvoljnom preciznošću poznavati određene parove fizičkih veličina, primjerice, položaj i impuls čestice ili energiju i vrijeme. Recimo da je $\Delta x$ određeno područje gdje se elektron ima naći u atomu vodika, tada je prema Heisenbergu neodređenost impulsa koju će elektron imati dok god se zadržava unutar rečenog područja: $\Delta p \approx \hbar / \Delta x$ (odnosno barem jednaka toj vrijednosti ili veća). Kinetička energija koja korespondira tom rasponu impulsa bit će: $E_{\mathrm{k}}=p^{2} /(2 m) \approx \hbar^{2} /\left(2 m \Delta x^{2}\right)$. $\hbar$ je reducirana Planckova konstanta $(h / 2 \pi)$ a $m$ masa elektrona. Potencijalna energija u atomu vodika jednaka je električnoj potencijalnoj energiji između protona i elektrona: $E_{\mathrm{p}}=-k \mathrm{e}^{2} / \Delta x$. $\pm \mathrm{e}$ je iznos naboja elektrona odnosno protona a $k$ Coulombova konstanta. Postavlja se pitanje postoji li minimum energije za elektron $\mathrm{u}$ atomu? To bi bio minimum ukupne energije elektrona, za što valja zbrojiti kinetičku i potencijalnu energiju i izračunati prvu derivaciju zbroja $(W)$ :

$$
\begin{gathered}
W \approx \frac{\hbar^{2}}{2 m(\Delta x)^{2}}-\frac{k \mathrm{e}^{2}}{\Delta x^{\prime}} \\
\frac{\partial W}{\partial x} \approx \frac{-\hbar^{2}}{m(\Delta x)^{3}}+\frac{k \mathrm{e}^{2}}{(\Delta x)^{2}} \approx 0, \\
\Delta x \approx \frac{\hbar^{2}}{k m e^{2}} .
\end{gathered}
$$

Dakle, postoji minimum energije za $\Delta x$ iz (5), što je upravo Bohrov radijus $\left(0,529 \cdot 10^{-10} \mathrm{~m}\right)$. Ako postoji minimum, znači da se elektron ne može bez dodatnog utroška energije potisnuti u niže stanje. Stoga, jednom kad elektron zauzme najniže energijsko stanje, on tamo i ostaje, dakle atom je stabilan i ne zrači kad se nalazi u osnovnom stanju. Stabilnost atoma možemo razumjeti kao posljedicu ravnoteže između privlačnog elektrostatičkog međudjelovanja elektrona s jezgrom i tzv. elektronskog tlaka koji proizlazi iz neodređenosti impulsa danog Heisenbergovom relacijom, kao gore. Međutim, atom je stabilan u svakom energijskom stanju u kojem se nađe, postavlja se, stoga, pitanje što elektron nagoni na kvantni skok u niži energijski nivo, dakle kako se zbiva spontana emisija? Na to pitanje odgovor daje sljedeći u nizu razvijenih modela atoma.

\section{Kvantnoelektrodinamički model}

Kvantna elektrodinamika, ${ }^{11}$ kako joj naziv kazuje, kvantna je verzija Maxwellove elektrodinamike, gdje se elektromagnetsko zračenje proučava kao kvantizirano u obliku fotona, a pojednostavljeno govoreći, to je grana fizike koja se bavi interakcijama fotona i elektrona. Kvantna elektrodinamika prva je razvijena od kvantnih teorija polja, skupine teorija koje istodobno zadovoljavaju uvjete kvantne teorije (poput kvantizacije nekih veličina) kao i uvjete specijalne 
teorije relativnosti (o nepostojanju apsolutnog referentnog sustava i konačnosti brzine svjetlosti). Ponekad se za kvantne teorije polja tvrdi da se tu radi o drugi put provedenoj kvantizaciji, u smislu da su, za razliku od kvantne teorije, tu kvantizirani i energija i materija i to u svim situacijama. Međutim može se ustvrditi i jače: da su tek kvantne teorije polja zapravo kvantizirane, jer je pretpostavka kvantizacije ugrađena otpočetka, u obliku operatora, kao i samog prostora nad kojim djeluju (tzv. Fockov prostor), dok se u kvantnoj teoriji dodaje ad hoc, postulirajući ju na kraju u obliku tzv. postulata kolapsa valne funkcije ${ }^{12}$ (pri čemu kontinuirana valna funkcija pri mjerenju ili općenito interakciji zauzima točno određenu vrijednost). Glavni operatori kvantne elektrodinamike su tzv. operatori stvaranja i poništavanja, koji, redom, stvaraju čestice iz kvantnog vakuuma ili poništavaju (anihiliraju) čestice tako da se masa čestica u potpunosti pretvori u energiju.

1950-ih nizozemski fizikalni kemičar Hendrik Casimir otkrio je posve slučajno da vakuum nije isto što i prazan prostor. Pri posebnim uvjetima (iznimno dobre izolacije sustava mikroskopskih dimenzija) čestice se pojavljuju iz vakuuma ili nestaju u vakuum. Ubrzo je shvaćeno da to nije slučaj tek pri pomno odabranim parametrima, već da su tzv. virtualne čestice općenito ključne za razumijevanje interakcija na kvantnoj razini. Naime, fizičku interakciju (ili kemijsku vezu) možemo razumjeti i kao izmjenu čestica intermedijara (posrednika) između čestica izvora interakcije. Intermedijari se nazivaju virtualnim česticama jer, premda su prisutni pri svakoj fizičkoj interakciji, moguće ih je opaziti isključivo pri posebnim uvjetima. Dakle, elektrostatičko privlačenje protona i elektrona u vodikovu atomu stalno je praćeno izmjenom virtualnih fotona (kao nositelja elektromagnetske interakcije), odnosno promjenom gustoće roja izmjenjivanih fotona, ali to ne znači da oko atoma vodika opažamo ikakvo zračenje, barem ne dok se on nalazi u nekom od stacionarnih stanja. Međutim intermedijari su stvarni i identični s onima otkrivenima u Casimirovu eksperimentu. Dapače, virtualni fotoni koje opskrbljuje kvantni vakuum, kao prostor u kojem prebivaju atomi, odgovorni su za spontane emisije iz atoma! Činjenicu da jednom kad se elektron nađe u stacionarnom stanju, on može tamo provesti cijelu vječnost, ali uvijek (obično vrlo brzo) dođe do emisije, ne objašnjava niti Bohrov niti kvantnoteorijski model atoma. Nešto mora izbaciti elektron iz položaja ravnoteže, neka perturbacija. U slučaju induciranog prijelaza među nivoima to je energija koju odredi eksperimentator, ali u slučaju spontane emisije perturbaciju uzrokuje sam vakuum. ${ }^{15}$ Kvantni vakuum zamišljamo kao okolinu atoma, molekula i subatomskih čestica koja posjeduje određenu minimalnu energiju i koja vječito fluktuira oko energijskog minimuma. Kvantne fluktuacije pravi su razlog postojanja a to znači i stabilnosti atoma, kao i kvantnih skokova unutar atoma ili molekula. Mehanizam (ili bolje rečeno struktura) kvantnih fluktuacija, koje su u načelu nasumične, nije poznat. Kvantne fluktuacije uzrok su i tzv. prirodnim širinama spektralnih linija, s obzirom na to da, prema Heisenbergovoj relaciji, za par veličina energija-vrijeme, ne posve određenom vremenu elektronovog prijelaza odgovara i pripadajuća neodređenost u emitiranoj (apsorbiranoj) energiji.

Vratimo se još jednom pitanju elektronskih putanja u atomu. Bohr i Heisenberg na kraju su se opredijelili na to da ne postavljaju to pitanje i to se, uz druge postulate, naziva kopenhagenska interpretacija kvantne teorije. Međutim ona već desetljećima gubi pristaše i trenutačno vlada poprilična zbrka u pristupu tumačenju osnovnih ideja ili eksperimenata kvantne teorije. Jedan od prvih izazivača kopenhagenske hegemonije bio je David Bohm, iznimno zaslužan za daljnji razvoj kvantne teorije nakon 1950. U Bohmovoj interpretaciji, ${ }^{19}$ koja je deterministička (i prema tome ima svoje probleme!) eksplicitno se raspravlja pojam elektronove putanje oko jezgre te se tvrdi da elektron u npr. $1 \mathrm{~s}$ stanju vodikova atoma - miruje. Dakako, to je nemoguće u okviru standardne elektrodinamike, bilo Maxwellove ili kvantne, međutim Bohm uvodi tzv. kvantni potencijal koji uravnotežuje kulonski i drži elektron u osnovnom stanju. Mnogo realističniji je Feynmanov ${ }^{20}$ pristup problemu opisa gibanja u kvantnom svijetu.

Richard Feynman jedan je od utemeljitelja kvantne elektrodinamike za što je i primio Nobelovu nagradu. Njegova inačica formalizma pored apstraktnih veličina (tzv. fazora) koje služe računanju kvantnih vjerojatnosti kao i vrijednosti fizičkih veličina uvodi kvantne čestice i klasične predodžbe poput putanje čestica. Međutim, putanja u Feynmanovoj elektrodinamici shvaćena je mnogo apstraktnije negoli u Newtonovoj mehanici. Dočim je za Newtona putanja nekog objekta uvijek stvarna i jedinstvena, tj. u nekom prostoru i određenog trajanja i samo jedna za pojedini primjer gibanja, za Feynmana je putanja stvarna, ali nikada i jedinstvena. Kako je to moguće? Recimo da elektron kreće od točke A prema točki B. Kako je elektron kvantni objekt, on (uz određene početne uvjete) ima na izbor više od jedne putanje, dapače ima ih praktički beskonačno mnogo! Naime, prema Feynmanu (a što potvrđuju rezultati eksperimenata!) elektron zapravo od A do B može dospjeti na bilo koji fizički realistično zamisliv način, ali kako svaki alternativni pravac ima svoju vjerojatnost, neke su putanje vjerojatnije od drugih. U konačnici, elektron najčešće bira upravo najvjerojatniju putanju (koja odgovara i najmanjoj vrijednosti tzv. klasičnog djelovanja ili akcije, vremenskom integralu razlike kinetičke i potencijalne energije čestice). Svaki put, pri svakom mjerenju, elektron bira drugu putanju, ali u najvećem broju navrata putanju minimalnog djelovanja, koja je i najvjerojatnija. Slično su i Bohrove dopuštene orbite, koje odgovaraju stacionarnim stanjima, zapravo tek najvjerojatnije putanje (ili bolje rečeno zbirovi najvjerojatnijih položaja, s obzirom na to da se elektron ne može kontinuirano gibati da ne izrači svu energiju), dok se elektron oko jezgre u realnom vremenu zapravo može zateći bilo gdje oko jezgre, pa i bilo kako daleko - čak i na jezgri!

DRUGI VELIKI ZAKLJUČAK ATOMISTIČKOG MODELA: Vakuum nije posve prazan, već iz njega mogu nastati i u njega nestati čestice!

\section{Kvantnokromodinamički model}

Još je jedno temeljno pitanje na koje je tek nedavno dan iznimno bizaran odgovor: odakle atomu masa? U školi se dugo vremena učilo da je većina mase u atomu koncentrirana u jezgri, tj. u protonima i neutronima, dočim se elektrone po masi može zanemariti. Odnedavna se čak i 
u školama spominje tzv. Higgsov mehanizam, koji navodno daje masu protonima i neutronima, tj. kvarkovima od kojih se ovi sastoje. Godine 2012. otkrivena je Higgsova (ili Božja) čestica, kvant Higgsova polja u interakciji s kojim ostale čestice dobivaju masu. Međutim, sva masa u atomu, a to znači i u poznatoj tvari, nije od Higgsova mehanizma, zapravo vrlo malo jest: svega $3 \%$ mase atoma! Odakle onda masa atomima?

Iz računa ${ }^{21}$ kvantne kromodinamike (onog dijela teorije polja koji se bavi kvarkovima i jakom nuklearnom interakcijom) proizlazi da kada se dva ili više kvarkova povezuju izmjenjujući gluone kao intermedijare jake nuklearne interakcije, dolazi do promjena u gluonskom polju koje inače postoji u kvantnom vakuumu. Stvaraju se tzv. kanali gluonskog fluksa (engl. gluon flux tubes) pri čemu se energija kvarkovskog sustava poveća (slika 4). Dakle, da bi se gluonsko polje razrijedilo - i posljedično, vakuum između kvarkova učinio više praznim - valja utrošiti energiju. Dodatna energija u sustavu manifestira se, kako to omogućuje Einsteinova ekvivalencija mase i energije (prema $E=m c^{2}$ ), kao dodatna masa koja zapravo čini $97 \%$ mase atomske jezgre, a to znači i atoma i sve tvari.

\section{TREĆI VELIKI ZAKLJUČAK ATOMISTIČKOG MODELA: Većini mase atoma porijeklo je u praznini!}

\section{Zaključak}

Moderni modeli atoma nameću opći zaključak da atomi na nerazdruživ način ovise o praznini ili, točnije, kvantnom vakuumu. Tri velika zaključka već su povučena: svemir je ne samo većinom prazan prostor u kojem se gibaju atomi, već su i atomi pretežno prazni! Vakuum nije posve prazan, već iz njega mogu nastati i u njega nestati čestice! Većini mase atoma porijeklo je u praznini! Doista, veza između atoma i praznine vrlo je dalekosežna: nedavna ${ }^{22}$ teorijska

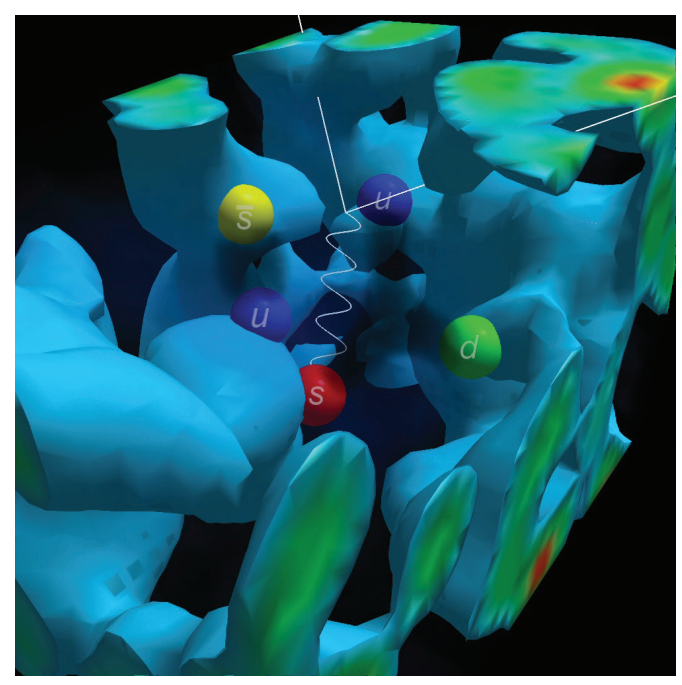

Slika 4 - Kvantnokromodinamički model protona, kvarkovi (označeni slovima) među sobom razmiču okolno gluonsko polje i stvaraju kanale gluonskog fluksa. Zanimljivo je da u protonu ne moraju nužno biti samo tri kvarka, kao što se obično kaže, već bilo koji neparni broj kvarkova. (Ljubaznošću profesora Dereka Leinwebera, CSSM, Sveučilište u Adelaideu.)

Fig. 4 -Quantum chromodynamical model of proton, quarks (denoted by letters) clearing amongst themselves the quantum gluon field and creating gluon flux tubes. It is interesting that a proton is not necessarily made out of only three quarks, as usually said, but can actually be built out of any odd number of quarks. (Courtesy Professor Derek Leinweber, CSSM, University of Adelaide.)

istraživanja potvrđuju ono što se već nekoliko desetljeća naslućivalo, da je postojanje atoma upravo takvih kakvi jesu, s određenim spektralnim linijama i drugim svojstvima, moguće jedino u svemiru s tri prostorne dimenzije jer bi u svemirima različitog broja dimenzija spektru npr. vodikova atoma nedostajala Balmerova serija. Posljednji zaključak bio bi: dimenzionalnost prostora, osim ostaloga, određuje postoje li atomi! 


\section{Literatura \\ References}

1. V. Paar, Fizika 4: udžbenik za 4. razred gimnazije, ŠK, Zagreb, 2009., str. 1-60.

2. D. Turčinović, I. Halasz, Opća kemija 1: udžbenik kemije u prvom razredu gimnazija, ŠK, Zagreb, 2015., str. 48-77.

3. I. Supek, Povijest fizike, ŠK, Zagreb, 1990., str. 137-169.

4. J. R. Partington, A Short History of Chemistry, 3rd Ed., Dover Publications Inc., New York, 1957., str. 153-180.

5. L. L. White, Boscovich and particle theory, Nature 179 (1957) 284-285, doi: https://doi.org/10.1038/179284a0.

6. I. Supek, Ruđer Bošković - vizionar u prijelomima filozofije, znanosti i društva, ŠK, Zagreb, 2005., str. 105-121.

7. E. Rutherford, The Scattering of $\alpha$ and $\beta$ Particles by Matter and the Structure of the Atom, Phil. Mag. 21 (1911) 669688, doi: https://doi.org/10.1080/14786440508637080.

8. D. Grdenić, Povijest kemije, Novi liber/ŠK, Zagreb, 2001. str. 729-905.

9. L. Pauling, General Chemistry, $3^{\text {rd }}$ Ed., Dover Publications, Inc., New York, 1988., str. 108-148.

10. A. Pais, Inward Bound: Of Matter and Forces in the Physical World, Oxford University Press, Oxford, 1988., str. 163-208.

11. A. Pais, Ibid., str. 324-621.

12. D. Bohm, Quantum Theory, Dover Publications Inc., New York, 1989., str. 59-80.
13. D. Bohm, Ibid., str. 116-140.

14. A. I. M. Rae, Quantum Mechanics, $4^{\text {th }}$ Ed., Institute of Physics Publishing, Bristol-Philadelphia, 2002., str. 1-59.

15. M. Grba, Što je atomska orbitala?, Kem. Ind. 67 (2018) 421426, doi: https://doi.org/10.15255/KUI.2018.035.

16. E. Schrödinger, Are There Quantum Jumps I?, Brit. J. Phil. Sci. 3 (1952) 109-123, doi: https://doi.org/10.1093/bjps/ III.10.109.

17. E. Schrödinger, Are There Quantum Jumps II?, Brit. J. Phil. Sci. 3 (1952) 233-242, doi: https://doi.org/10.1093/bjps/ III.11.233.

18. P. A. Cox, Introduction to Quantum Theory and Atomic Structure, Oxford University Press, Oxford, 1996., str. 36-46.

19. D. Bohm, A Suggested Interpretation of the Quantum Mechanics in Terms of "Hidden" Variables. I, Phys. Rev. 85 (1952) 166-179, doi: https://doi.org/10.1103/PhysRev.85.166.

20. R. P. Feynman, QED. The Strange Theory of Light and Matter, Penguin, London, 1990.

21. F. Bissey, F. G. Cao, A. R. Kitson, A. I. Signal, D. B. Leinweber, B. G. Lasscock, A. G. Williams, Gluon Flux-tube Distribution and Linear Confinement in Baryons, Phys. Rev. D 76 (2007) 114512-114528, doi: https://doi.org/10.1103/PhysRevD.76.114512.

22. F. Burgbacher, C. Lämmerzahl, A. Macias, Is there a Stable Hydrogen Atom in Higher Dimensions?, J. Mat. Phys. 40 (1999) 625-635, doi: https://doi.org/10.1063/1.532679.

\section{SUMMARY}

\section{Models of the Atom in the $20^{\text {th }}$ and $21^{\text {st }}$ Centuries \\ Marko Grba}

The model of the atom has been contemplated since ancient Greece up to, roughly, the first half of the $20^{\text {th }}$ century and one might even say that we know everything there is to know about atoms. Many facts are learned already in high school, but the average Physics or Chemistry student thinks little of how the electrons move inside the atom, or from where atoms get their mass. Indeed, how do atoms exist at all? What are the conditions of their stability? Here, we give a survey of what we know about the atom today, of the history of the models of the atom in the past hundred years or so, as well as some still unanswered questions about the atom.

\section{Keywords}

Models of the atom, Bohr's model, quantum mechanical model, quantum electrodynamical model, quantum chromodynamical model

First Croatian Grammar School of Sušak

Gajeva 1

51000 Rijeka

Croatia
Professional paper

Received January 20, 2019 Accepted March 8, 2019 